\title{
Influence of Peer Group on the Career Choice of Secondary School Students in South Senatorial District of Edo State, Nigeria
}

\author{
William Akporobaroh Oduh, James Odunayo Agboola*, Faith Aiwanehi Eibhalemen \\ Department of Education, Benson Idahosa University, Benin City.Edo State.
}

*Corresponding Author: James Odunayo Agboola, Department of Education, Benson Idahosa

University, Benin City.Edo State.

\begin{abstract}
The study investigated the influence of peer group on secondary school students' career choice in South Senatorial District of Edo State. Specifically, the study investigated the level of peer influence on career choice and influence of peer group on career choice by gender in public secondary schools in South Senatorial District of Edo State. The study was a correlational survey employing the Ex-Post-Facto research design and the population of the study comprised of 140 public secondary schools with 13, 265SSII students in South Senatorial District of Edo State. A total of 306 public secondary school students drawn from the public senior secondary schools in South Senatorial District of Edo State were used as the sample for the study. This was selected using a simple random sampling technique. The research instrument used for this study was a questionnaire. The data collected were analysed using the descriptive statistics of mean, standard deviation and the Pearson Product Moment Correlation statistics. Findings revealed that students were not moved to choose a particular career because their friends were going into that profession; there was a significant influence of peer group on students' career choicesandthere was no significant difference in the influence of peer group between male and female students in their choice of career in public secondary schools in the South Senatorial District of Edo State. Based on the findings, it was recommended that Schools, in collaboration with the Ministry of Education, should endeavour to organize at least one mandatory career programme that will involve professionals and experts from various fields of life. Such programme should be coordinated by the guidance counsellor.
\end{abstract}

\section{BACKGROUND To THE STUDY}

Career choice is an indispensable decision made by adolescents as they progress in high school. While this decision process starts early for some adolescents from enriched environment the process comes late for some other adolescents who could not come to terms with themselves as a sequel to inability to identify what they would like to become in future. Obviously, making career decision is predicated on information at the disposal of the adolescent. Indeed, a multiplicity of internal and external variables could combine to fast track or delay the career decisions by adolescents. Commenting on career, Alutu (2017) says:

Career refers to a person's professional course or an occupation which he/she has to follow over a number of years, affording him/her the opportunity for progress as well as serving as his principal means of earning a living and in which he/she is generally recognised to have become fairly an expert in, through experience (P. 297).

On their part, Olaosebikan\&Olusakin (2014: 44) see career as "a person's progress or general course of action through a phase of life, in some profession or undertaking" Career can be explained as the sum total of life experiences, including paid and unpaid work, community, voluntary and family activities.

Making a decision concerning the selection of suitable career or occupation is one significant problem facing senior secondary school students and young adolescents in general. This may be due to lack of information, understanding, orientation, awareness, training and opportunities about activities in different careers or vocations. This takes us to the issue of career choice. Career Choice refers to the process whereby an individual makes up his mind in favour of a particular career or occupation at a given time after thorough consideration of other alternatives. Occupational selection, as a 
developmental procedure spanning almost throughout a person's life, is one of the most difficult and key decision one has to make in a life time. This choice ought to be made with the understanding of the necessary demands or implications of entering into the career area. This is why a student needs to be systematically furnished with relevant career information to enable him/her make a realistic career decision.

The complexities noted above about career choice have compelled many young people to seek assistance from members of the age group in an attempt to resolve the seeming impasse. This refers to "the influence a peer group exerts on an individual that encourages the individual to change his or her attitude, values or behaviour to conform to such a group" (Kirk, 2000: 133). Apart from the influence exerted by parents, some students may want to identify with their friends in the class. Hence, they choose subject combinations which would lead to certain careers simply because a friend belongs to that particular group. Arab, Gohar, Waseem, Nasim, Irum\&Nasar(2014) carried out a study titled "Peer and Friends and Career Decision Making: A Critical Analysis." The discourse was based on content analysis as well as field information which explored the nature, level and extent of peer and friends influence in career decision making process of an individual. The data were collected through library method, which is, searching relevant books, journals, articles, newspapers and even internet sources while field information was obtained through questionnaire from 100 students using random sampling method. All the collected data were critically analysed, debated and explained to produce theory for generalization while the field information was analysed in the form of frequencies and percentages using the chi-square test. The analysis and discussion, thus gave rise to an argument that although family, that is parents and other family members, primarily work to transform the behaviour of the children in multiple ways, peer influence is an asset for developing career opportunities and decision making among youth.

In a related development, Mohd\& Abdul (2015) carried out a study titled "Parental and Peer Influences upon Accounting as a Subject and Accountancy as a Career". The study investigated the level of influence between parents and peers of Malaysian school students in selecting their career choice as accountants. The study used a mixed approach of both qualitative and quantitative approaches. The sample comprised 309 secondary school students studying Accounting or Commerce as respondents to the research. The findings revealed that parents, and mothers, in particular, were more influential in the career choice of secondary school students compared to their peers. The study found that parents' education did not influence their children's choice of career.

Similarly, Salami \& Salami (2013) carried out a study on "The Factors Determining Choice of Career among Secondary School Students. The purpose of the study was to investigate the influence of students' environment, personality and opportunity on their career choices in Ogun State. 100 students were randomly selected from five secondary schools in Ogun state. The sample consisted of 37 males and 63 females. A questionnaire designed and with Likert response format was used for data collection. Their responses were analysed using percentage, mean, standard deviation and t-test at $\mathrm{p}<0.05$ level of significance. Significant difference was found on the environmental factor (tcal at $\mathrm{p}<0.05=220.25$, tcrit $=1.960$ ). Significant difference was also found on the personality (tcal at $\mathrm{p}<0.05=673.48$;tcrit1.960)and the significant difference of the opportunity the students see (tcal at $\mathrm{p}<0.05=148.69$;tcrit 1.960 ). $52 \%$ of male and $46 \%$ of female respondents agreed that opportunity influenced career while $42 \%$ disagreed for both male and female, $51 \%$ of male and $51 \%$ of female agreed that personality influenced career choice while $42 \%$ and $45 \%$ of both male and female respectively disagreed. $50 \%$ of male and $54 \%$ of female agreed that environment influenced career choice but $41 \%$ and $49 \%$ of male and female disagreed. One can, therefore, conclude that while students did not feel environmental factors were important, they did not show outright disregard for it. Conclusively, all the factors affected the students in determining their career.

In a study, Igbinedion (2011) investigated the "Perceived factors that influence students' vocational choice of secretarial studies in tertiary institutions in Edo state of Nigeria. The factors investigated included parents, peer group, gender and interest. This was informed by the low enrolment into secretarial education programmes across the universities and colleges of education and the poor attitude of students with regard to their self-worth in spite of the many job opportunities and career satisfaction offered by this all pervasive skill oriented vocational academic programme. The design of the study was descriptive with a stratified sample of 191 subjects randomly selected from a population 
of 447 students enrolled in secretarial studies programmes in public tertiary institutions in Edo State during the 2006/2007 academic session. A questionnaire was the instrument used to gather data from the field for analysis. Two research questions and two hypotheses guided the study. The results showed that there were variations in the perceived factors that influence students' vocational choice of secretarial studies between male and female students. Also, students from the universities and colleges of education differed significantly with regard to some of the factors that influenced their choice. Based on these, conclusions were drawn and recommendations made.

Another study was carried out by Dodge \&Welderufael (2014) titled "Factors that Influence Career Choice in South African Township High School Students." The study was to find out if the legacy of apartheid was apparent in the lack of educational resources for Black South African high school students and the occupational deprivation they experience. The following factors were considered as barriers students' face. These include: parental absence, lack of role models, poverty, and the educational context and environment of disadvantaged communities in South Africa. A questionnaire was used to collect data on students' perception of career choice in township high schools. It was a descriptive study using both quantitative and qualitative data methods in collection and analysing data. From the study it was observed that a significant difference was found based on gender in relation to having career options and with regard to how knowledge about careers was gained. Despite occupational deprivation, students were hopeful about the future. In conclusion, the results indicated that majority of black South African 9th grade students' felt they had a choice of career, which was significant considering that during the apartheid period black South Africans were limited in their career choices.

From the empirical review within the reach of the researchers, it was observed that not much work had been carried out on peer group influence on career choice, especially within Edo South Senatorial District, Edo State. This is the gap this study filled.

\section{Statement of the Problem}

The global economic meltdown in early 2008 made the world economy to take a downward turn and Nigeria, as country, was not insulated from the effect of this meltdown. So many people lost their jobs not just as a result of downsizing the labour force but, also, as a result of aptitude under utilisation in industries. There has been general unemployment, and especially, graduate unemployment which still persists. Despite government effort in introducing skills oriented training programmes into secondary and tertiary level of education in the country, unemployment rate is drastically increasing day-by-day. Hence there is the need for young adolescents to make the right career choices that can give them a competitive edge.

In addition, it has been observed that many Nigerian students encounter a lot of problems while making career choices. This difficulty may arise from making choices in consonance with extraneous influences such as the peer group members rather than consulting the professionally trained guidance counsellor. Unfortunately, most secondary schools in Edo state have no practising guidance counsellors. The result of this situation is frustration, as many youths have gone into occupations for which they do not have the aptitude or interest. They lack self-confidence and ability to make career choices on their own. This is the concern of this study. It has become necessary to investigate the role of peer group in career decisions. The concern of this study, stated in a question form, therefore, is: could the influence of peer group be a determinant of career choices made by secondary school students in the South Senatorial District of Edo State?

\subsection{Purpose of the Study}

The purpose of the study was to find out how peer influence relates to career choice among students in senior secondary schools in South Senatorial District of Edo state. Specifically, the study investigated the:

1. level of peer influence on career choice; and

2. Influence of peer group on career choice by gender.

\subsection{Research Questions}

The following research questions were addressed in this study: 
1. What is the level of peer group influence on career choice?

2. Is there a difference in the influence of peer group between male and female students in their career choices?

\subsection{Hypotheses}

1. There is no significant influence of peer group on students' career choices.

2. There is no significant difference in the influence of peer group between male and female students in their choices of career

\subsection{Scope of the Study}

The study was conducted in the South Senatorial District of Edo State. Variables investigated include: Peer group influence on career choices and peer group influence on male and female students in their career choices in secondary schools.

\section{Methodology}

\subsection{Research Design}

The study was a correlational survey employing the Ex-Post-Facto research design. This design was considered suitable since the study sought to determine the relationship between the independent variables (peer influence) and the dependent variable (career choice).

\subsection{Population of the Study}

The population for the study was made up of all SS II students in all the public secondary schools in the South Senatorial District, Edo State. This Senatorial District is made up of seven Local Government Areas. There are one hundred and forty (140) public secondary schools in the area of study with thirteen thousand, two hundred and sixty-five $(13,265)$ SSII students (Ministry of Education, Benin City). This number formed the population of the study.

\subsection{Sample and Sampling Technique}

The sample for the study was three hundred and six (306) students selected from six public mixed secondary schools in the South Senatorial district, Edo State. The schools were selected using systematic sampling technique. The class of interest was SS II and of the correctly filled questionnaire, 114 (37.4\%) and 192 (62.6\%) copies belonged to males and females respectively. The recorded statistics showed that more female students participated in the study.

\subsection{Research Instrument}

The research instrument, which is the questionnaire, had two sections, A and B. Section A contained the demographic variables while sections B contained a total of thirty items. The items were scored thus: "Very Low" (1), "Low" (2), "Moderate" (3) "High" (4), and "Very High" (5). The items were generated to reflect the research questions. Items in section B were raised to measure peer group influences on career choice.

\subsection{Validity of the Instrument}

To determine the face and content validity of the instrument, the researchers sought the expert judgment of three lecturers: two in guidance and counselling and one in measurement and evaluation. All suggested corrections were effected and incorporated into the final instrument.

\subsection{Reliability of the Instrument}

In determining the reliability of the instrument, the split-half method was used. The instrument was administered on 20 SS II students outside the proposed sample. Data generated were analysed using the Cronbach Alpha statistics to ascertain the internal consistency of the instrument. This yielded coefficient of .75 , which showed that the instrument was good and could be used for eliciting responses from respondents.

\section{Method of Data Collection}


Influence of Peer Group on the Career Choice of Secondary School Students in South Senatorial District of Edo State, Nigeria

The researchers administered the questionnaire personally on the respondents in their various schools. The completed copies of the questionnaire were collected from the respondents immediately on completion in order to prevent possible misplacement.

\subsection{Method of Data Analysis}

Descriptive and inferential statistics were used in this study. The descriptive statistics of mean, standard deviation and percentage counts were used in analysing the research questions while the Pearson correlation statistics was used in testing hypothesis one and the students' independent t-test was used in testing hypothesis two. The hypotheses were testedat 0.05 level of significance.

\section{RESUlts}

\section{Research Question one: What is the level of peer group influence on career choice?}

The respondents in the survey were asked to rank the extent to which the various components influenced their career choice. Ranking was done on a five point scale from very low (1) to very high (5).

Table1. Peer Group Influence on Career choice

\begin{tabular}{|c|c|c|c|c|c|c|c|c|}
\hline $\mathrm{S} / \mathrm{N}$ & $\begin{array}{l}\text { To what extent did any of } \\
\text { the following items } \\
\text { influence your career } \\
\text { choice }\end{array}$ & $\begin{array}{l}\text { Very } \\
\text { Low } \\
(\text { VL) }\end{array}$ & $\begin{array}{l}\text { Low } \\
\text { (L) }\end{array}$ & $\begin{array}{l}\text { Moderate } \\
\text { (M) }\end{array}$ & $\begin{array}{l}\text { High } \\
\text { (H) }\end{array}$ & $\begin{array}{l}\text { Very } \\
\text { High } \\
\text { (VH) }\end{array}$ & $\begin{array}{l}\text { Mean } \\
(\mathrm{M})\end{array}$ & SD \\
\hline 1 & $\begin{array}{l}\text { Desire to choose a particular } \\
\text { subject because friends } \\
\text { chose the same subject. }\end{array}$ & $\begin{array}{l}195 \\
(64.1 \%)\end{array}$ & $\begin{array}{l}85 \\
(28 \%)\end{array}$ & $\begin{array}{l}14 \\
(4.6 \%)\end{array}$ & $\begin{array}{l}4 \\
(1.3 \%)\end{array}$ & $\begin{array}{l}6 \\
(2.0 \%)\end{array}$ & 1.49 & .812 \\
\hline 2 & $\begin{array}{l}\text { Habit of skipping some } \\
\text { classes because of friends. }\end{array}$ & $\begin{array}{l}204 \\
(64.1 \%)\end{array}$ & $\begin{array}{l}61 \\
(20.2 \%)\end{array}$ & $\begin{array}{l}22 \\
(7.3 \%)\end{array}$ & $\begin{array}{l}8 \\
(2.6 \%)\end{array}$ & $\begin{array}{l}7 \\
(2.3 \%)\end{array}$ & 1.52 & .914 \\
\hline 3 & $\begin{array}{l}\text { Attending a particular career } \\
\text { workshop/seminar because } \\
\text { of friends. }\end{array}$ & $\begin{array}{l}167 \\
(55.7 \%)\end{array}$ & $\begin{array}{l}72 \\
(24.0 \%)\end{array}$ & $\begin{array}{l}44 \\
(14.7 \%)\end{array}$ & $\begin{array}{l}13 \\
(4.3 \%)\end{array}$ & $\begin{array}{l}4 \\
(1.3 \%)\end{array}$ & 1.72 & .959 \\
\hline 4 & $\begin{array}{ll}\text { Missing a particular career } \\
\text { workshop/ } & \text { seminar because } \\
\text { friends } & \text { considered it } \\
\text { irrelevant. } & \end{array}$ & $\begin{array}{l}178 \\
(59.1 \%)\end{array}$ & $\begin{array}{l}71 \\
(23.6 \%)\end{array}$ & $\begin{array}{l}35 \\
(11.6 \%)\end{array}$ & $\begin{array}{l}8 \\
(2.7 \%)\end{array}$ & $\begin{array}{l}9 \\
(3.0 \%)\end{array}$ & 1.67 & .988 \\
\hline 5 & $\begin{array}{l}\text { Influenced to choose subject } \\
\text { because of friends good } \\
\text { performance in the subject }\end{array}$ & $\begin{array}{l}156 \\
(52.3 \%)\end{array}$ & $\begin{array}{l}69 \\
(23.2 \%)\end{array}$ & $\begin{array}{l}40 \\
(13.4 \%)\end{array}$ & $\begin{array}{l}18 \\
(6.0 \%)\end{array}$ & $\begin{array}{l}15 \\
(5 \%)\end{array}$ & 1.88 & 1.159 \\
\hline 6 & $\begin{array}{l}\text { Choice of subject because of } \\
\text { anticipated peers assistance }\end{array}$ & $\begin{array}{l}143 \\
(48 \%)\end{array}$ & $\begin{array}{l}59 \\
(19.8 \%)\end{array}$ & $\begin{array}{l}49 \\
(16.4 \%)\end{array}$ & $\begin{array}{l}29 \\
(9.7 \%)\end{array}$ & $\begin{array}{l}18 \\
(6.0 \%)\end{array}$ & 2.08 & 1.348 \\
\hline 7 & $\begin{array}{l}\text { Refusal to choose certain } \\
\text { subject because of friends } \\
\text { poor performance in the } \\
\text { subject }\end{array}$ & $\begin{array}{l}171 \\
(59 \%)\end{array}$ & $\begin{array}{l}57 \\
(19.7 \%)\end{array}$ & $29(10 \%)$ & $\begin{array}{l}20 \\
(6.9 \%)\end{array}$ & $\begin{array}{l}13 \\
(4.5 \%)\end{array}$ & 1.78 & 1.152 \\
\hline 8 & Influence of tutorial group & $\begin{array}{l}106 \\
(37.1 \%)\end{array}$ & $\begin{array}{l}62 \\
(21.7 \%)\end{array}$ & $\begin{array}{l}64 \\
(22.4 \%)\end{array}$ & $\begin{array}{l}34 \\
(11.9 \%)\end{array}$ & $\begin{array}{l}20 \\
(7.0 \%)\end{array}$ & 2.30 & 1.271 \\
\hline 9 & Sharing of study materials & $\begin{array}{l}63 \\
(21.5 \%)\end{array}$ & $\begin{array}{l}40 \\
(13.7 \%)\end{array}$ & $\begin{array}{l}85 \\
(29 \%)\end{array}$ & $\begin{array}{l}58 \\
(19.8 \%)\end{array}$ & $\begin{array}{l}42 \\
(16.0 \%)\end{array}$ & 2.95 & 1.357 \\
\hline \multirow[t]{2}{*}{10} & $\begin{array}{l}\text { Friends admission into } \\
\text { prestigious professions }\end{array}$ & $\begin{array}{l}104 \\
(35.5 \%)\end{array}$ & $\begin{array}{l}59 \\
(20.1 \%)\end{array}$ & $\begin{array}{l}72 \\
(26.6 \%)\end{array}$ & $\begin{array}{l}32 \\
(10.9 \%)\end{array}$ & $\begin{array}{l}26 \\
(8 . \% 9)\end{array}$ & 2.38 & 1.304 \\
\hline & $\begin{array}{l}\text { AVERAGE PEER GROUP } \\
\text { INDEX }\end{array}$ & $\begin{array}{l}54 \\
(17.9 \%)\end{array}$ & $\begin{array}{l}39 \\
(13 \%)\end{array}$ & $\begin{array}{l}69 \\
(22.9 \%)\end{array}$ & $\begin{array}{l}68 \\
(22.6 \%)\end{array}$ & $\begin{array}{l}71 \\
(23.6 \%)\end{array}$ & 1.99 & .747 \\
\hline
\end{tabular}

Source: Author's field work (2016)

Table 1 showed that peer group influence on career choice of secondary school students was low with an average mean of 1.99 representing approximately low index on the Likert scale of $1-5$. The examination of the different measures of peer group influence on career choice showed that the desire to choose a particular subject on the account that a friend was offering the same subject was weakly or lowly influenced with a mean of 1.49. Consequently, students did not choose or select their subjects 
Influence of Peer Group on the Career Choice of Secondary School Students in South Senatorial District of Edo State, Nigeria

solely because their friends were offering the same subject. By implication, students were not moved to choose a particular career because their friends were going into that profession.

Research Question two: Is there a difference in the influence of peer group between male and female students in their career choices?

The summary of the result is presented in Table 2

Table2. Descriptive statistics on the difference in the influence of peer group between male and female students in their career choices

\begin{tabular}{|l|l|l|l|l|}
\hline Gender & N & SD & Mean & Mean Difference \\
\hline Male & 114 & 1.56 & 22.94 & 0.02 \\
\cline { 1 - 4 } Female & 192 & 1.51 & 22.96 & \\
\hline
\end{tabular}

Table 2 showed that the male students had peer group influence mean score of 22.94 with standard deviation of 1.56 while the female had the peer group influence mean score of 22.96 , standard deviation of 1.51 with a mean difference of 0.02 in favour of the female students. It can be concluded from the table therefore, that, there is a difference in the influence of peer group between male and female students in their career choices, however, the female students had the higher peer group influence mean score than their male counterparts in the public school.

\section{Hypothesis One: There is no significant influence of peer group on students' career choices.}

Table3. Pearson Correlation on the Relationship Between peer group on students' career choices.

\begin{tabular}{|l|l|l|l|l|l|l|}
\hline Var. & Mean & SD & R & $\mathbf{r}^{2}$ & Sig.(2-tailed & Decision \\
\hline Peer Influence & 22.96 & 1.52 & .20 & 0.04 & 0.00 & Significant \\
\hline Career choice & 39.70 & 4.12 & & & & \\
\hline
\end{tabular}

Table 3 showed that the mean score of peer group influence was 22.96 with a standard deviation of 1.52 while the students' career choice was 39.70 with a standard deviation of 4.12 . The table also showed that there was a very low positive relationship (0.20) between peer group influence and students' career choice. The coefficient of determination $\left(\mathrm{r}^{2}\right)$ associated with the correlation coefficient of 0.20 was 0.04 and this relationship is significant at 0.00 . Since 0.00 is less than 0.05 , the null hypothesis was rejected. Thus, there was a significant influence of peer group on students' career choices.

\section{Hypothesis Two: There is no significant difference in the influence of peer group between male and female students in their choice of career}

The results displayed in Table 4.

Table4. Summary of the t-test analysis of difference in the influence of peer group between male and female students in their choice of career

\begin{tabular}{|l|l|l|l|l|l|l|}
\hline Gender & $\mathbf{N}$ & $\mathbf{t}$ & Mean & Mean diff.df & Sig.(2-tailed) & Decision \\
\hline Male & 114 & & 22.94 & & & \\
\hline & & -0.11 & & 0.02304 & 0.90 & Accept Ho \\
\hline Female & 192 & 22.96 & & & & \\
\hline
\end{tabular}

Table 4 showed that the difference in the influence of peer group between male and female students in their choice of careeris not significant at $0.90(\mathrm{t}=-0.11 ; \mathrm{df}=304)$. Since 0.90 is higher than 0.05 , the observed difference between the male and female students regarding the influence of peer group on their career choice is not significant. With this, the null hypothesis which says there is no significant difference in the influence of peer group between male and female students in their choice of careeris accepted. This showed that there was no significant difference in the influence of peer group between male and female students in their choice of career.

\section{DISCUSSION}

One of the findings in this study revealed that peer group influence on career choice of secondary school students was low. By implication, students were not moved to choose a particular career because their friends were going into that profession. The result of the present study is in line the findings of Mohd\& Abdul (2015) which revealed that parents, and mothers in particular, were more 
influential in career choice of the secondary school students compared to their peers. Although, while testing the corresponding hypothesis, it revealed that there was a significant influence of peer group on students' career choices. This finding supported the results ofArab et al (2014) who noted that peer influence is an asset for developing career opportunities and decision making among youth. The study's result, also supported the findings of Bankole\&Ogunsakin (2015) who found that peer relationship has a great influence in determining academic performance and, by extension, career choice.

Another finding in this study showed that there is no significant difference in the influence of peer group between male and female students in their choice of career. This finding disagreed with the study of Dodge \&Welderufael (2014) who observed that there was a difference in the relationship between gender and career choice. The comparative analysis of career choice between male and female students showed that more males were interested in engineering, while more females indicated their desire to study Nursing and Medicine.

\subsection{Educational/Counselling Implications}

The above research findings, no doubt, have far-reaching implications for counsellors, educationist, and parents.

1. The findings of this study can stimulate in educationists the need to employ more counsellors not only in secondary schools but also in the university system where young adolescents are found. This would help to reduce problem of inappropriate career choice by young persons.

2. The finding on gender influence on career choice would motivate the counsellors in organising career-day programmes for their students.

3. The findings on peer group influence and career choice would help counsellors and parents have a better insight on the level of peer influence among secondary school students.

4. The findings would be useful to researchers and individuals working in the guidance and psychological centres in schools as bases for enlightening young people during career seminars and workshops.

\subsection{Contribution to Knowledge}

The study has made significant contributions to the body of knowledge in the area of career choice among secondary school students and no such work has been carried out within the South Senatorial District of Edo State, Nigeria. The study provides useful information for counsellors and educationists for better understanding of peer group influences on the choice of career among the adolescents. The study also surveyed students' preference for the three subject area: Arts, Sciences and Social Sciences, in terms of peer group influence.

\section{CONCLUSION}

The influence from peer group on career choice as evident in this study was significant. As implicated by this study, females were found to be more influenced by their peers than the male counterparts. This means that peer group still wields some influence on the career choices of secondary students.

\section{RECOMMENDATIONS}

1. To make guidance services available to all secondary schools, States and Federal Governments should endeavour to employ qualified counsellors.

2. Schools, in collaboration with the Ministry of Education, should endeavour to organize at least one mandatory career programme that will involve professionals and experts from various fields of life. Such programme should be coordinated by the guidance counsellor.

\section{REFERENCES}

[1] Alutu, A. N. G. (2017). Theory and practice of guidance and counselling. Benin City: Mindex Publishing Company.

[2] Arab, N., Gohar, S., Waseem, K., Nasim, K., Irum, S.\&Nasar, K. ( 2014).Peer and friends and career decision making: A critical analysis. Middle-east journal of scientific research, 22 (8), 1193-1197. 
[3] Bankole, E. T.\&Ogunsakin, F. C. (2015). Influence of peer group on academic performance of secondary school students in Ekiti State. International Journal of Innovative Research \& Development , 4 (1), 2278 - 0211 (Online)

[4] Dodge, E. A. \&Welderufael, M. (2014). Factors that influence career choice in South African Township High School Students. Unpublished Master's Theses and Capstone submitted in partial fulfilment of the requirements for graduation in the School of Health and Natural Sciences, Dominican University of California. San Rafael, California.

[5] Igbinedion, V. I. (2011).Perception of factors that influence students' vocational choice of secretarial studies in tertiary institutions in Edo state of Nigeria. European Journal of Educational Studies, 3(2),325337.

[6] Kirk, A.M. (2000). Riding the bull: Reform in Washington, Kentucky, and Massachusetts, Journal of Health Politics, Policy and Law, 25 (1), 133-173.

[7] Mohd, H. \& Abdul, M. .E. (2015). Parental and peer influences upon accounting as a subject and accountancy as a career. Journal of Economics, Business and Management, 3, (2), 252-256.

[8] Olaosebikan, O.I. \&Olusakin, A. M. (2014).Effects of parental influence on adolescents' career choice in Badagry Local Government Area of Lagos State, Nigeria Journal of Research \& Method in Education, 4457 www.iosrjournals.org

[9] Salami, O. O. \& Salami, O.O. (2013). The factors determining the choice of career among secondary school students. The International journal of engineering and science (IJES), (6), 33-44.

Citation: William Akporobaroh Oduh, et.al. "Influence of Peer Group on the Career Choice of Secondary School Students in South Senatorial District of Edo State, Nigeria" International Journal of Humanities Social Sciences and Education (IJHSSE), vol 7, no. 6, 2020, pp. 214-221. doi: http://dx.doi.org/10.20431/23490381.0706023 .

Copyright: () 2020 Authors. This is an open-access article distributed under the terms of the Creative Commons Attribution License, which permits unrestricted use, distribution, and reproduction in any medium, provided the original author and source are credited. 